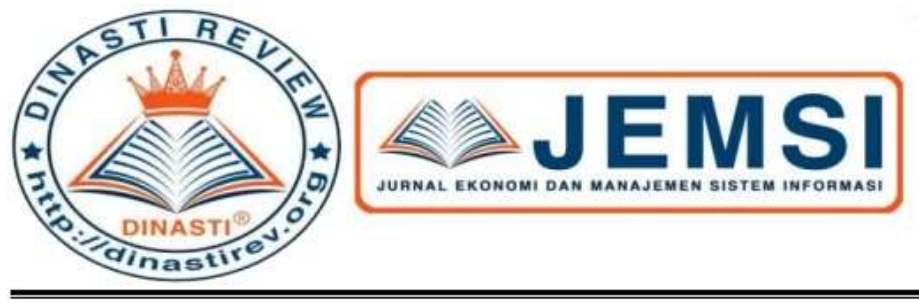

+62 878-9658-6407

087896586407 (ㅇ)

https://dinastirev.org/JEMSI (7)

editor@dinastirev.org@.

\title{
STRATEGI PENGEMBANGAN INFRASTRUKTUR DALAM MENINGKATKAN PELAYANAN PENUMPANG DI BANDAR UDARA INTERNASIONAL SOEKARNO HATTA CENGKARENG
}

\section{Muhammad Shobirin ${ }^{1}$, Hapzi Ali ${ }^{2}$}

1) Universitas Mercu Buana, Jakarta, Indonesia

2) Universitas Mercu Buana, Jakarta, Indonesia

ARTICLE INFORMATION

Received: 15 Desember 2019

Revised: 20 Desember 2019

Issued: 31 Desember 2019

(filled in by Editor)

Corresponding author: first author

E-mail:

mshobirin19@gmail.com hapzi.ali@mercubuana.ac.id

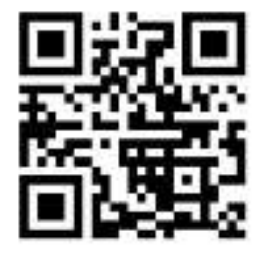

DOI:10.31933/JEMSI
Abstrak: Pembangunan infrastruktur bandar udara dimaksudkan untuk meningkatkan pelayanan pada masyarakat pengguna transportasi udara. Tujuan penelitian untuk mengetahui strategi pengembangan infrastruktur Bandara Internasional Soekarno Hatta dalam meningkatkan pelayanan penumpang di bandara berdasarkan faktor internal dan faktor eksternal bandar udara. Penelitian ini menggunakan metode deskriptif kualitatif dengan metode analisis data yaitu analisis SWOT, IFAS, EFAS dan Matrix SWOT. Tehnik pengumpulan data secara kuesioner dalam mengkaji faktor internal (kekuatan dan kelemahan) dan eksternal (peluang dan ancaman). Hasil analisis SWOT menunjukkan bahwa Bandara Internasional SoekarnoHatta dengan total nilai rata-rata tertimbang 2,885 pada matrix IFAS menunjukkan strategi perusahaan dalam memanfaatkan kekuatan dan meminimalkan kelemahan berada di atas rata-rata dan kondisi internal perusahaan cenderung kuat. Sedangkan nilai faktor eksternal Bandara Internasional Soekarno-Hatta di atas rata-rata 2,5, Bandara Internasional Soekarno-Hatta harus tetap berupaya maksimal untuk memanfaatkan peluang eksternal dan menghindari ancaman yang dapat mempengaruhi perusahaan. Terdapat empat alternatif strategi yang dapat diterapkan Bandara Internasional Soekarno Hatta Cengkareng yaitu SO, WO, ST, WT sehubungan dengan pengembangan infrastruktur dalam meningkatkan pelayanan penumpang di Bandara Internasional Soekarno Hatta Cengkareng.

Kata Kunci: Pengembangan infrastruktur, analisis SWOT, alternatif Strategi 


\section{PENDAHULUAN}

Transportasi udara (penerbangan) sebagai salah satu sub sektor transportasi yang termuda telah menunjukkan perkembangan yang pesat (the youngest but the fastest). Kemajuan di bidang penerbangan telah merubah wajah dan peta perkembangan perekonomian, mobilitas penduduk, dan pembangunan secara luas. Untuk itu pembangunan infrastruktur bandar udara harus direncanakan kapasitasnya agar mampu melayani kegiatan penerbangan terutama penumpang yang cenderung meningkat cepat. Pembangunan infrastruktur mempunyai peranan sebagai penunjang dalam menggerakkan dinamika pembangunan, memperlancar mobilitas manusia, barang, dan jasa serta mendukung peningkatan hubungan secara nasional dan internasional.

Direktorat Jenderal Perhubungan Udara Kementerian Perhubungan terus melakukan peningkatan layanan dan membangun infrastruktur Bandar Udara di berbagai daerah. Pembangunan infrastruktur bandar udara dimaksudkan untuk meningkatkan pelayanan pada masyarakat pengguna transportasi udara. Pada dasarnya, permasalahan kapasitas akan menyebabkan efek domino tersendiri bagi arus lalu lintas di Bandara. Penumpang yang setiap tahun terus meningkat akan merasa kurang nyaman karena semakin padatnya penumpang yang tidak dimbangi dengan perluasan kapasitas serta penambahan fasilitas yang mendukung kenyamanan penumpang sehingga akan menyebabkan kerugian tersendiri bagi penumpang (Destiani, 2014).

Bandara merupakan bagian dari pelayanan penumpang harus memiliki kinerja pelayanan yang baik agar menghasilkan pelayanan yang lancar, aman, nyaman, handal, dan berkemampuan tinggi serta diselenggarakan secara terpadu, tertib, efektif, dan efisien. Bandar udara selama ini telah dipersepsikan sebagai pintu gerbang suatu daerah, wilayah bahkan negara dan juga telah menjadi simbol prestise tersendiri yang akan diingat oleh penumpang pesawat udara baik domestik maupun internasional. Bahkan saat ini pelayanan bandara yang prima akan menjadi refleksi dari keberhasilan perusahaan.

Untuk memiliki kinerja tersebut, bandar udara harus telah memenuhi penilaian yang mengacu pada peraturan dan perundang-undangan. Berdasarkan hal ini Kementerian Perhubungan telah menginstruksikan kepada seluruh pengelola bandar udara di seluruh Indonesia untuk meningkatkan pelayanan kepada penumpang. Bandar Udara Internasional Soekarno-Hatta merupakan sebuah bandar udara utama yang melayani penerbangan domestik dan internasional. Bandara Internasional Soekarno Hatta juga sebagai bandar udara transit berbagai Negara sekaligus merupakan pintu gerbang di Indonesia mempunyai nilai strategis. Total penumpang di Bandara Internasional Soekarno-Hatta pada akhir tahun 2018 ini diprediksi mencapai 67 Juta lebih. Untuk pergerakan pesawat dari Januari hingga September 2018 realisasi pertumbuhan rata-rata mencapai 5\%. Sedangkan untuk pertumbuhan penumpang rata-rata mencapai $7 \%$.

Sebagaimana diuraikan pada latar belakang, permasalahan pokok yang dihadapi adalah bagaimana strategi perkembangan infrastruktur yang dilakukan oleh pengelola bandara dalam peningkatan pelayanan penumpang di bandara berdasarkan kombinasi dari faktor internal dan faktor eksternal bandar udara?. Tujuan Penelitian untuk mengetahui strategi pengembangan infrastruktur Bandara Internasional Soekarno Hatta dalam meningkatkan pelayanan penumpang di bandara berdasarkan faktor internal dan faktor eksternal bandar udara. 


\section{KAJIAN PUSTAKA}

Pengertian Strategi

Pengertian strategi menurut pendapat para ahli ada beberapa macam. Kata strategi berasal dari kata strategos dalam bahasa Yunani merupakan gabungan dari Stratos atau tentara dan ego atau pemimpin. Menurut Stephanie K. Marrus yang di kutip Fatoni (2015) menyatakan bahwa "strategi adalah proses penentuan rencana para pemimpin puncak yang berfokus pada tujuan jangka panjang organisasi, disertai penyusunan suatu cara atau upaya bagaimana agar tujuan tersebut dapat dicapai. Menurut Pearce dan Robinson, strategi adalah rencana main dari suatu perusahaan, yang mencerminkan kesadaran suatu perusahaan mengenai kapan, dimana dan bagaimana ia harus bersaing dalam menghadapi lawan dengan maksud dan tujuan tertentu.

Strategi pengembangan merupakan suatu kegiatan untuk mencapai tujuan dalam organisasi dengan tujuan pencapaian efektifitas dalam suatu tujuan organisasi, dengan pencapaian kerjasama yang baik atar individu dan organisasi (Siagian, 2000). Menurut Hajisarosa P (1980) dalam Liu, dkk (2009), strategi pengembangan diartikan sebagai penjabaran upaya-upaya yang perlu dilaksanakan untuk mencapai sasaran. Strategi dan sasaran merupakan proses yang bersifat interaktif, karena strategi senantiasa harus terkait dengan sasaran. Strategi pengembangan merupakan langkah yang perlu ditempuh untuk mewujudkan keadaan keseimbangan, walaupun dengan tingkat perataan yang rendah.

Menurut Moenir (2006) dalam Yuliana (2015) pelayanan adalah proses pemenuhan kebutuhan melalui aktivitas orang lain secara langsung. Pelayanan yang diperlukan manusia pada dasarnya ada 2 (dua) jenis, yaitu layanan fisik yang sifatnaya pribadi sebagi manusia dan layanan administratif yang diberikan oleh orang lain selaku anggota organisasi, baik itu organisasi massa atau negara. Pelayanan secara umum adalah kegiatan yang dilakukan oleh seseorang atau kelompok orang dengan landasan faktor materiil melalui sistem, prosedur dan metode tertentu dalam rangka usaha memenuhi kepentingan orang sesuai dengan haknya (Sinambela, 2010 dalam Yuliana 2015).

Menurut Parasuraman et al (1990) dalam Tangkilisan (2008) Kualitas layanan meliputi lima dimensi yaitu:

(1) Tangibles meliputi fasilitas fisik, perlengkapan, personilnya dan sarana komunikasi. Hal ini berkaitan dengan fasilitas fisik, penampilan karyawan, peralatan dan teknologi yang dipergunakan dalam memberi layanan, fasilitas fisik seperti gedung, ruang tempat layanan, kebersihan, ruang tunggu, fasilitas musik, AC, tempat parkir merupakan salah satu segi dalam kualitas jasa karena akan memberikan sumbangan bagi konsumen yang memerlukan layanan perusahaan. (2) Reliability (kehandalan), yaitu kemampuan untuk menghasilkan kinerja pelayanan yang dijanjikan secara akurat dan pasti.

Hal ini berarti bahwa pelayanan harus tepat waktu dan dalam spesifikasi yang sama, tanpa kesalahan, kapanpun pelayanan tersebut diberikan. (3) Responsiveness (keikutsertaan), yaitu kemampuan para karyawan untuk membantu para pelanggan dan memberikan layanan dengan tanggap. Hal ini tercermin pada kecepatan, ketepatan layanan yang diberikan kepada pelanggan, keinginan karyawan untuk membantu para pelanggan (misal: customer service memberikan informasi seperti yang diperlukan pelanggan. (4) Empathy, yaitu kemudahan dalam melakukan hubungan, komunikasi yang baik, perhatian pribadi dan memahami kebutuhan pelanggan. 
Hal ini berhubungan dengan perhatian atau kepedulian karyawan kepada pelanggan (misal: untuk menemui karyawan senior), kemudahan mendapatkan layanan (berkaitan dengan banyaknya outlet, kemudahan mendapatkan informasi melalui telepon). Kepedulian karyawan terhadap masalah yang dihadapinya. Perusahaan memiliki objektifitas yaitu: memperlakukan secara sama semua pelanggan.

\section{Infrastruktur}

Secara umum, definisi infrastruktur dapat dijelaskan sebagai suatu sistem fasilitas fisik yang mendukung kehidupan, keberlangsungan dan pertumbuhan ekonomi dan sosial suatu masyarakat atau komunitas. Infrastruktur yang dimaksud dalam penelitian ini mengacu pada ketersediaan sarana prasarana penunjang. Dalam konteks infrastruktur di Indonesia, infrastruktur di Indonesia lebih dikenal dengan prasarana (Kamus Besar Bahasa Indonesia). Sarana memiliki sifat mobile seperti mobil, kereta dan lain sebagainya. Sedangkan prasarana memiliki sifat tidak mobile dan merupakan elemen pendukung kegiatan perkotaan seperti jalan, lahan parkir dan jembatan (Rifka, 2010).

Infrastruktur bandar udara meliputi komponen teknis, tenaga kerja dan administratif. Komponen teknis berupa bangunan dan struktur, landasan pacu, lampu suar aerodrome, kendaraan, pengatur lalu lintas udara, fasilitas radar, komunikasi, ruang tunggu dan situs web. Tenaga kerja berupa personel keamanan, personel landasan pacu, agen tiket, pengawas bandar udara, penangan bagasi, pengatur lalu lintas udara, jabatan manajemen, dll.Komponen administratif berupa organisasi, struktur yang cocok untuk lanjutan dan lain-lainnya (https://id.wikipedia.org/wiki/Infrastruktur_bandar_udara).

\section{Pengertian SWOT}

Analisa SWOT (strenght, weakness, opportunity, treads) merupakan salah satu metode dalam melakukan penyusunan strategi perusahaan dengan melihat kondisi lingkungan perusahaan baik itu lingkungan internal maupun eksternal. Analsis SWOT digunakan untuk melihat kekuatan, kelemahan, peluang dan ancaman yang akan dihadapi oleh perusahaan. SWOT menurut Sutojo dan F. Kleinsteuber (2002) adalah untuk menentukan tujuan usaha yang realistis, sesuai dengan kondisi perusahaan dan oleh karenanya diharapkan lebih mudah tercapai. SWOT adalah singkatan dari katakata strength (kekuatan perusahaan) weaknesses (kelemahan perusahaan), opportunities (peluang bisnis) dan threats (hambatan untuk mencapai tujuan).

Sedangkan Kotler (2008) mengemukakan bahwa analisis SWOT adalah evaluasi terhadap keseluruhan kekuatan, kelemahan, peluang dan ancaman disebut analisis SWOT. Menurut Graffin (2004), analisis SWOT adalah evaluasi atas kekuatan (strengths) dan kelemahan (weaknes) internal suatu organisasi yang dilakukan secara berhatihati, dan juga evaluasi atas peluang (opportunities) dan ancaman (threats) dari lingkungan. Dalam analisis SWOT, stategi terbaik untuk mencapai misi suatu organisasi adalah dengan mengeksploitasi peluang dan kekuatan suatu organisasi, dan pada saat yang sama menetralisasikan ancamannya, dan menghindari atau memperbaiki kelemahannya (Nizak, 2013).

Unsur - unsur SWOT yaitu kekuatan (Strenght), kelemahan (weakness), peluang (Opportunity), ancaman (Threats). Menurut (fahmi, 2013:260) untuk menganalisis secara lebih dalam tentang SWOT, maka perlu dilihat faktor eksternal dan internal sebagai bagian penting dalam analisis SWOT, yaitu: Faktor eksternal. Faktor eksternal ini mempengaruhi 
terbentuknya opportunities and threats $(\mathrm{O}$ dan $\mathrm{T})$. Dimana faktor ini menyangkut dengan kondisi-kondisi yang terjadi di luar perusahaan yang mempengaruhi dalam pembuatan keputusan perusahaan.

Faktor ini mencakup lingkungan industri dan lingkungan bisnis makro, ekonomi, politik, hukum, teknologi, kependudukan, dan sosial budaya. Sedangkan Faktor internal mempengaruhi terbentuknya strenghts and weaknesses ( $\mathrm{S}$ dan $\mathrm{W}$ ). Dimana faktor ini menyangkut dengan kondisi yang terjadi dalam perusahaan, yang mana ini turut mempengaruhi terbentuknya pembuatan keputusan (decision making) perusahaan. Faktor internal ini meliputi semua macam manajemen fungsional : pemasaran, keuangan, operasi, sumberdaya manusia, penelitian dan pengembangan, sistem informasi manajemen dan budaya perusahaan (corporate culture).

Langkah pertama dalam analisis SWOT adalah melakukan pengumpulan data. Pada tahap ini yang dilakukan tidak hanya sekedar mengumpulkan data, tetapi juga melakukan proses pengklasifikasian dan pra analisis. Data yang ada dibedakan menjadi dua yaitu data eksternal dan internal. Data eksternal diperoleh dari lingkungan eksternal perusahaan seperti misalnya analisis pasar, kompetitor, pemasok, regulasi pemerintah serta perubahan sosial budaya pada masyarakat.

Sedangkan data internal yang biasanya berasal dari dalam perusahaan biasanya berupa laporan keuangan, laporan kegiatan sumber daya manusia, laporan kegiatan operasional dan pemasaran. Langkah berikutnya dalam analisis SWOT adalah membuat sebuah lembaran kerja dengan menarik sebuah garis persilangan yang membentuk empat kuadran, masingmasing untuk kekuatan, kelemahan, peluang dan ancaman (Sulistiani, 2015). Kuadran I : Pada situasi kuadran 1 berada pada situasi yang paling menguntungkan. Posisi pada kuadran I, berarti perusahaan mempunyai peluang dan kekuatan. Strategi yang harus diambil dalam kondisi seperti ini adalah mendukung kebijakan pertumbuhan yang agresif atau growth oriented strategy dengan memanfaatkan peluang yang ada serta kekuatan internal yang dimiliki perusahaan. Kuadran II: Pada suatu perusahaan yang telah melakukan identifikasi mengenai kekuatan inti akan menghadapi situasi lingkungan yang tidak menguntungkan. Walaupun mempunyai ancaman dari lingkungan eksternal, perusahaan masih mempunyai kekuatan dari internal perusahaan yang bisa digunakan sebagai nilai tambah.

Dalam situasi seperti ini, strategi yang harusnya diterapkan oleh perusahaan adalah menggunakan kekuatan yang dimilikinya yaitu sumber daya dan kompetensinya untuk memanfaatkan peluang jangka panjang dengan melakukan diversifikasi. Kuadran III:perusahaan memiliki peluang yang sangat besar dari pasar tetapi perusahaan mempunyai kelemahan dari sumber daya internal. Fokus dari strategi perusahaan yang berada dalam kondisi seperti ini harusnya adalah menghilangkan kelemahan internal sehingga dapat berkonsentrasi pada mengejar peluang pasar yang tersedia. Kuadran 4: Posisi ini merupakan situasi yang paling tidak menguntung kan bagi perusahaan. Hal ini disebabkan karena perusahaan selain mempunyai hambatan pada faktor ekternalnya yaitu adanya ancaman dari pasar, juga mempunyai hambatan pada sumber daya internal. Situasi tersebut tentu saja membutuhkan strategi yang dapat mengurangi atau bahkan dapat mengarahkan kembali keterlibatan produk atau pasar yang telah ditelaah menggunakan analisa SWOT. 


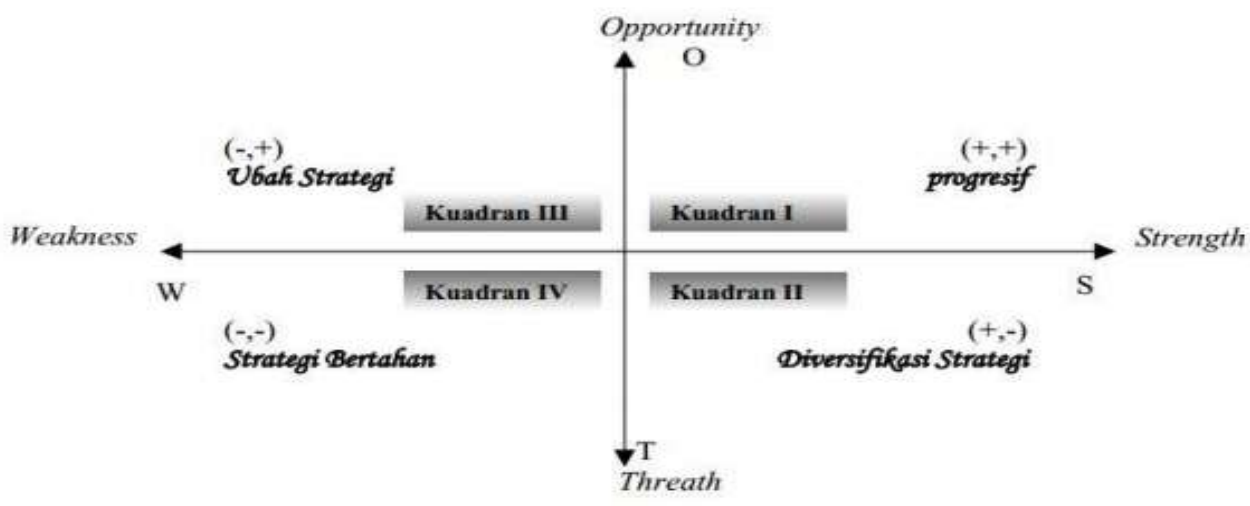

Gambar 1. Analisis SWOT Sebuah Perusahaan

\section{METODE PENELITIAN}

Penelitian ini dilakukan pada Pengelola Bandara yaitu Bandara Internasional Soekarno Hatta yang berada di Cengkareng. Penelitian ini difokuskan pada penilaian kualitas pelayanan penumpang khususnya kepada penumpang pesawat udara yang menerima jasa pelayanan dari PT. (Persero) Angkasa Pura II sebagai pengelola bandar udara Internasional Soekarno Hatta. Untuk memperoleh informasi dan data yang diperlukan dalam penulisan ini maka digunakan tehnik pengumpulan data secara Kuesioner, yaitu penyebaran kuisioner kepada narasumber dalam mengkaji faktor internal (kekuatan dan kelemahan) dan eksternal (peluang dan ancaman).

Penelitian ini menggunakan analisis deskriptif kualitatif. Analisis deskriptif adalah proses mengatur, mengurutkan, mengelompokan, memberi kode, mengkategorikan, mengartikan, dan menginterpretasikan data/informasi kualitatif dan kuantitatif. Metode analisis yang digunakan untuk menjawab permasalahan yang dikemukakan adalah analisis kualitatif yaitu analisis SWOT, untuk mengetahui nilai IFAS (Internal Strategic Factors Analysis System), nilai EFAS (External Strategic Factors Analysis System) dan matrix SWOT (Rangkuti, 2006). Analisis SWOT digunakan untuk mengetahui keunggulan dan kelemahan serta peluang dan ancaman yang dihadapi oleh Bandara Internasional Soekarno Hatta Cengkareng dalam peningkatan pelayanan penumpang di bandara.

\section{HASIL DAN PEMBAHASAN}

Adapun fokus dari penelitian ini adalah analisis SWOT yaitu evaluasi terhadap keseluruhan kekuatan, kelemahan, peluang dan ancaman. Berdasarkan hasil kuisioner telah dapat diidentifikasi faktor-faktor internal dan ekternal pengembangan pelayanan penumpang di Bandara Internasional Soekarno Hatta - Cengkareng pada Tabel 1 berikut ini.

\section{Tabel 1.}

Identifikasi Faktor Internal dan Eksternal

\begin{tabular}{l|l}
\hline \multicolumn{1}{c|}{ FAKTOR INTERNAL } & \multicolumn{1}{c}{ FAKTOR EKSTERNAL } \\
\hline KEKUATAN & PELUANG \\
Fasilitas Terminal yang sudah berstandar & Meningkatnya jumlah Penumpang di Terminal \\
Internasional & $\begin{array}{l}\text { Terbukanya kesempatan menarik pembeli di area } \\
\text { Fasilitas Jalan yang Tanpa gangguan }\end{array}$ \\
Fasilitas Transportasi Penghubung yang efektif & $\begin{array}{l}\text { Meningkatnya traffic kendaraan di area Bandara } \\
\text { Fasilitas Cargo yang aman dan rapih }\end{array}$ \\
Fasilitas Penginapan yang tersedia di area & menggunakan jumlah penumpang yang \\
Bandara & Pengantaran bisnis barang meningkat \\
\hline
\end{tabular}




\begin{tabular}{|c|c|}
\hline KELEMAHAN & ANCAMAN \\
\hline Kurangnya Fasilitas Toilet yang disediakan & Berkurangnya Penumpang yang datang ke Bandara \\
\hline $\begin{array}{l}\text { Kurangnya Transportasi penghubung yang } \\
\text { diberikan }\end{array}$ & $\begin{array}{l}\text { Terjadi kemacetan dalam kawasan dalam dan luar } \\
\text { bandara }\end{array}$ \\
\hline $\begin{array}{l}\text { Buruknya kualitas fasilitas pendukung di dalam } \\
\text { penginapan }\end{array}$ & $\begin{array}{l}\text { Menurunya lalu lintas pengantaran barang } \\
\text { Kendaraan Taxi gelap yang merusak kondisi }\end{array}$ \\
\hline Stabilitas Jalan yang tidak nyaman & transportasi penghubung \\
\hline $\begin{array}{l}\text { Tidak terjaganya keamanan penyimpanan } \\
\text { Barang }\end{array}$ & Kurangnya minat pembeli di area konsesi \\
\hline
\end{tabular}

\section{Faktor Internal}

Dalam analisis SWOT, terdapat analisis internal yaitu suatu analisis lingkungan pada suatu perusahaan yang meliputi kekuatan (strengths) dan kelemahan (weaknesses). Perusahaan dapat memaksimalkan kekuatan namun secara bersamaan juga dapat meminimalkan kelemahan dengan kekuatan yang ada. Perusahaan harus bisa membaca kekuatan dan kelemahan, sehingga bisa digunakan sebagai daya saing dalam memasuki pasar. Kemampuan perusahaan dalam membaca analisis terhadap lingkungan internal, menjadi faktor determinan yang mampu menciptakan keunggulan dibandingkan para kompetitornya. Hal-hal yang bisa dimasukkan dalam lingkungan internal ini meliputi manajemen dan struktur organisasi, kebijakan organisasi, sumber daya keuangan, sumber daya manusia, sikap dan perilaku karyawan.nOleh karena itu, pada dasarnya faktor-faktor internal tersebut dapat dikendalikan oleh perusahaan.

\section{Kekuatan (Strenght)}

Kekuatan adalah suatu kunci bagi perusahaan untuk bertahan didalam persaingan dengan perusahaan lain sehingga berdampak pada suatu keunggulan bagi perusahaan itu sendiri. Dalam hal meningkatkan pelayanan penumpang, Organisasi Bandara Internasional Soekarno-Hatta memiliki kekuatan. Melakukan pengembangan usaha dalam bidang jasa kebandarudaraan dan peningkatan pelayanan yang optimal kepada pengguna jasa bandara melalui penyelenggaraan pelayanan-pelayanan yang menunjang jasa kebandarudaraan. Sebagai upaya dalam meningkatkan pelayanan penumpang, dilakukan pengembangan fasilitas untuk penunjang operasional. Salah satu penunjang operasional adalah dengan mengembangkan infrastruktur yang menghubungkan penumpang menuju Bandara dan keluar Bandara.

Bandara Internasional Soekarno-Hatta mempunyai SOP yang sudah berstandar Internasional dalam hal pelayanan dan penyediaan fasilitas Penunjang salah satunya adalah Bangunan Terminal. Terminal 3 merupakan salah satu dari ketiga Terminal yang memiliki kapasitas penumpang lebih besar dibandingkan dengan Terminal 1 dan Terminal 2. Dengan desain modern yang dimiliki Terminal 3, hal ini menjadi daya Tarik bagi penumpang domestic maupun Internasional. Adapun untuk mendukung penumpang agar dapat menuju Terminal dengan tepat waktu, Bandara menyediakan aksesibilitas jalan yang lebar sehingga tidak terjadi kemacetan dan antrian yang panjang.

Hal ini memberikan kesan yang baik dari sisi lalu lintas kendaraan di Kawasan Bandara. Tidak sampai di akses, Bandara juga memberikan pelayanan berupa Transportasi umum yang dapat digunakan oleh penumpang berupa Bus, Kereta, Taksi, dan Kalayang. Fasilitas yang memudahkan penumpang untuk menuju Terminal baik kedatangan maupun transit dari satu terminal ke terminal yang lain. Selain itu, Bandara memiliki fasilitas 
terminal kargo. Fasilitas tersebut untuk memberikan pelayanan dalam hal pengantaran barang dari suatu tempat menuju tempat lainnya. Di dalam pelayanan terminal kargo, barang tersusun dengan rapih dan aman sehingga pelayanan dan kualitas menjadi prioritas dalam hal kepuasan penumpang.

Untuk mewujudkan Bandara yang memberikan kenyamanan bagi penumpang, Bandara menyediakan hotel Domestik dan Internasional yang difungsikan memberikan kemudahan penumpang agar tidak berada jauh dari bandara. Untuk memaksimalkan pelayanan terbaik melalui penyediaan beragam pelayanan jasa penunjang bandar udara yang modern dengan ditunjang fasilitas berteknologi tinggi adalah komitmen Angkasa Pura II untuk mewujudkan kenyamanan bagi pengguna jasa selama berada di lingkungan bandara

\section{Kelemahan (Weaknesses)}

Bandara mempunyai kekurangan ataupun kelemahan baik dari Jumlah petugas operasional pelayanan bandara yang masih kurang maupun fasilitas yang sedang dalam perawatan. Sehingga terdapat kekurangan seperti keterbatasan fasilitas toilet yang mana beberapa fasilitas sedang dalam perbaikan. Sehingga hal ini menjadikan kelemahan bagi bandara internasional Soekarno-Hatta. Selain hal tersebut, terdapat kekurangan armada bus yang meghubungkan dari Terminal satu ke terminal yang lain.

Hal ini menjadikan antrian bagi penumpang untuk dapat menggunakan fasilitas bus yang dimaksud. Fasilitas penunjang dapat berupa jalan akses, sering ditemukan jalan yang terdapat lubang sehingga perjalanan kendaraan menuju bandara menjadi tidak nyaman. Perlu ditingkatkan dalam hal perawatan jalan baik menuju maupun keluar. Tidak terkecuali di tempat penginapan hotel, banyaknya keluhan di alami dari fasilitas pendukung di dalam penginapan baik berupa air yang bocor maupun listrik yang padam. Hal ini merupakan kelemahan yang harus diwaspadai dan diperbaiki dalam hal meningkatkan kualitas pelayanan.

\section{Faktor Eksternal}

Analisis eksternal yaitu suatu analisis lingkungan pada suatu perusahaan yang meliputi peluang (opportunities) dan ancaman (threats). Lingkungan eksternal adalah kekuatan di luar perusahaan yang dapat mempengaruhi perusahaan tetapi perusahaan tidak mempunyai daya untuk mengendalikannya. Menurut Wahyudi (1996), lingkungan eksternal ini terdiri dari lingkungan umum. Menurut Hitt (2005), Lingkungan umum merupakan sekumpulan elemen masyarakat yang lebih luas sehingga mampu mempengaruhi suatu industri dan perusahaan yang ada di dalamnya. Perusahaan harus lebih cermat dalam menghadapi lingkungan ini dengan mengambil peluang yang ada dan meminimalkan ancaman yang ada pada perusahaan. Karena pada dasaranya faktor-faktor eksternal tersebut tidak dapat dikendalikan oleh perusahaan.

\section{Peluang (opportunities)}

Bandara Internasional Soekarno Hatta merupakan bandara terbesar dengan peningkatan pertumbuhan angkutan udara setiap tahunnya sehingga peluang menjadi bandara yang sering digunakan transit dan transfer penumpang sangat besar. Meningkatnya jumlah penumpang di terminal menjadikan terminal sebagai pusat tempat berkumpulnya penumpang terbesar. Sehingga hal ini menjadi peluang yang besar dalam pengembangan fasilitas terminal. Dengan banyaknya penumpang, hal ini membuka 
kesempatan terjadinya jual beli di Kawasan bandara sehingga area konsesi menjadi konsen utama dalam meningkatkan pendapatan Bandara. Selain meningkatnya penumpang, kendaraan pun juga akan menjadi sangat padat, yang menyebabkan perlunya pengembangan aksesibilitas menuju Bandara yang didukung dengan ketersediaan transportasi umum di Kawasan Bandara. Namun dilihat dari sisi transportasi umum, jumlah ketersediaan kendaraan peril dilakukan penambahan penambahan armada transportasi baru yang nyaman bagi penumpang. Hal tersebut menjadi perhatian dalam menentukan peluang untuk mengembangkan Bandara dalam hal pelayanan lebih baik.

2. Ancaman (Threats)

Tingkat kepedulian penumpang yang masih kurang (kebersihan bandara, kepatuham terhadap rambu dll). Ketidakselarasan antara mitra kerja (CIQ) dengan pengelola bandara. Masih banyak pihak eksternal yang memanfaatkan bandara sebagai tempat mata pencaharian (taksi gelap, calo dan asongan). Taksi gelap yang dioperasikan perorangan juga banyak ditemui ketika keluar dari terminal kedatangan baik domestik maupun internasional. Taksi gelap ini menawarkan harga yang lebih murah dibanding dengan taksi resmi, tetapi tentunya belum tentu lebih murah dan tidaklah dianjurkan karena keselamatan tidak terjamin.

Tetapi kebanyakan terdapat taksi gelap yang menawarkan tarif belasan bahkan puluhan kali lipat lebih mahal dibandingkan dengan taksi resmi. Selain itu adanya kebijakan dalam hal tarif tiket pesawat, menyebabkan berkurangnya penumpang yang akan menggunakan fasilitas bandara. Hal ini menjadi ancaman besar bagi Perusahaan. Hal ini dirasakan dari sepinya pembeli dalam menggunakan fasilitas tenant dan konsesi. Terjadinya kemacetan di tol menuju Bandara menyebabkan antrian panjang yang menghambat penumpang untuk keluar dari Terminal. Hal ini menjadikan kemacetan yang panjang di area Bandara.

\section{Analisis SWOT}

Berdasarkan penentuan bobot faktor-faktor kekuatan dan kelemahan maka dapat dibuat faktor-faktor strategi yang hasilnya ditunjukkan pada Tabel 2. IFAS disusun untuk merumuskan faktor-faktor strategis internal dalam kerangka kekuatan (strength) dan kelemahan (weakness).

\section{Tabel 2.}

IFAS

\begin{tabular}{l|c|c|c}
\hline \multicolumn{1}{c|}{$\begin{array}{c}\text { Faktor - faktor Internal Kunci Bandara } \\
\text { Internasional Soekarno-Hatta }\end{array}$} & Bobot & Peringkat & Rata-Rata \\
\hline KEKUATAN & & & \\
\hline 1. Fasilitas Terminal yang sudah berstandar & 0,1235 & 4 & 0,4942 \\
Internasional & 0,0898 & 4 & 0,3593 \\
2. Fasilitas Jalan yang Tanpa gangguan & 0,1348 & 4 & 0,5394 \\
3. Fasilitas Transportasi Penghubung yang efektif & 0,0787 & 4 & 0,3148 \\
4. Fasilitas Cargo yang aman dan rapih & 0,1235 & 4 & 0,4942 \\
5. Fasilitas Penginapan yang tersedia di area Bandara & & & \\
KELEMAHAN & 0,1011 & 1 & 0,1011 \\
1. Kurangnya Fasilitas Toilet yang disediakan & 0,1124 & 1 & 0,1124 \\
2. Kurangnya Transportasi penghubung yang & & & 0,0787 \\
diberikan & 0,0787 & & \\
3. Buruknya kualitas fasilitas pendukung di dalam \\
penginapan
\end{tabular}


4. Stabilitas Jalan yang tidak nyaman

0,0674

5. Tidak terjaganya keamanan penyimpanan Barang

0,0898

0,1348

JUMLAH

1

0,0898

2,7189

Berdasarkan hasil dari hasil Matriks IFAS di atas, diketahui bahwa faktor internal Bandara Internasional Soekarno-Hatta mempunyai nilai 2,7189. Menurut David (2009), berapapun banyaknya faktor yang dimasukkan dalam Matriks IFAS, total nilai rata-rata tertimbang berkisar antara yang terendah 1,0 dan tertinggi 4,0, dengan rata-rata 2,5. Total nilai yang jauh di bawah 2,5 merupakan ciri organisasi yang lemah secara internal, sedangkan total nilai yang jauh di atas 2,5 menunjukkan ciri organisasi yang kuat secara internal. Bandara Internasional Soekarno-Hatta dengan total nilai rata-rata tertimbang 2,885 menunjukkan strategi perusahaan dalam memanfaatkan kekuatan dan meminimalkan kelemahan berada di atas rata-rata dan kondisi internal perusahaan cenderung kuat.

Hal ini sejalan dengan riset yang dilakukan oleh Yuliana (2015) yang menyatakan bahwa Dari hasil analisis nampak bahwa posisi PT Angkasa Pura II Cabang Bandara Soekarno Hatta menghadapi beberapa peluang dan mempunyai berbagai kekuatan yang mendorong untuk mendapatkan peluang peluang tersebut. Ini merupakan situasi yang sangat menguntungkan. Strategi yang harus diterapkan dalam kondisi ini adalah mendukung kebijakan pertumbuhan yang agresif (growth oriented strategy).

Berdasarkan penentuan bobot faktor-faktor peluang dan ancaman maka dapat dibuat faktor-faktor strategi yang hasilnya ditunjukkan pada Tabel 3. EFAS disusun untuk merumuskan faktor-faktor strategis dalam kerangka peluang dan ancaman.

\section{Tabel 3.}

EFAS

\begin{tabular}{l|c|c|c}
\hline \multicolumn{1}{c|}{$\begin{array}{c}\text { Faktor-faktor Eksternal Kunci Bandara } \\
\text { Internasional Soekarno-Hatta }\end{array}$} & Bobot & Peringkat & Rata-Rata \\
\hline PELUANG & & & \\
\hline 1. Meningkatnya jumlah Penumpang di Terminal & 0,1392 & 4 & 0,5568 \\
$\begin{array}{l}\text { 2. Terbukanya kesempatan menarik pembeli di area } \\
\text { konsesi }\end{array}$ & 0,1012 & 3 & 0,3036 \\
3. Meningkatnya traffic kendaraan di area Bandara & 0,1139 & 4 & 0,4558 \\
$\begin{array}{l}\text { 4. Bertambahnya jumlah penumpang yang } \\
\text { menggunakan }\end{array}$ & 0,1392 & 4 & 0,5568 \\
transportasi umum & & & \\
5. Pengantaran bisnis barang meningkat & 0,1012 & 4 & 0,4049 \\
\hline ANCAMAN & & & \\
1. Berkurangnya Penumpang yang datang ke Bandara & 0,0887 & 2 & 0,1774 \\
2. Terjadi kemacetan dalam kawasan dalam dan luar & 0,0760 & 2 & 0,1519 \\
$\begin{array}{l}\text { Bandara } \\
\text { 3. Menurunya lalu lintas pengantaran barang }\end{array}$ & 0,0760 & 1 & 0,0760 \\
$\begin{array}{l}\text { 4. Kendaraan Taxi gelap yang merusak kondisi } \\
\text { transportasi penghubung }\end{array}$ & 0,0887 & 2 & 0,1774 \\
5. Kurangnya minat pembeli di area konsesi & 0,0760 & 1 & 0,0760 \\
& 1 & & 2,9364 \\
\hline
\end{tabular}

Berdasarkan hasil dari hasil Matriks EFAS di atas, diketahui bahwa faktor eksternal Bandara Internasional Soekarno-Hatta mempunyai nilai 2,9364. Seperti pada matriks IFAS, berapapun jumlah peluang dan ancaman utama yang dimasukkan dalam matriks EFAS, total nilai rata-rata tertimbang berkisar antara yang terendah 1,0 dan tertinggi 4,0 dengan rata-rata 
2,5. Walaupun nilai faktor eksternal Bandara Internasional Soekarno-Hatta di atas rata-rata 2,5, Bandara Internasional Soekarno-Hatta harus tetap berupaya maksimal untuk memanfaatkan peluang eksternal dan menghindari ancaman yang dapat mempengaruhi perusahaan. Hasil ini juga masih sejalan dengan penelitian yang dilakukan Subekti (2016) nilai EFAS dari Bandara H. Hasan Aroeboesman sebesar 2.300.

Posisi relatif bandar udara H. Hasan Aroeboesman Ende terletak pada koordinat (-0.518 ;0.100) dan berada di kuadran 2 (dua). Hal ini berarti bandar udara H . Hasan Aroeboesman Ende memiliki Weakness Opportunity (WO) sehingga mendukung strategi turn around dengan memanfaatkan peluang-peluang untuk mengatasi/ menghadapi kelemahan.

\section{Matrix SWOT}

Matrik SWOT adalah alat yang dipakai untuk menyusun faktor-faktor strategis perusahaan. Matrik ini dapat mengambarkan secara jelas bagaimana peluang dan ancaman eksternal yang dihadapi perusahaan dapat disesuaikan dengan kekuatan dan kelemahan yang dimilikinya. Analisis dengan menggunakan model matrik SWOT ini menggunakan data yang diperoleh dari table faktor strategi internal dan faktor strategi eksternal Bandara Internasional Soekarno Hatta. Berdasarkan analisis menggunakan model Matrik SWOT maka dapat dibuat berbagai alternatif strategi yang dapat dikembangkan Bandara Internasional Soekarno Hatta di Tabel 4 berikut ini.

Tabel 4.

Matrix SWOT Pengembangan Infrastruktur Peningkatan Pelayanan Penumpang

\begin{tabular}{|c|c|c|}
\hline Faktor Internal & \begin{tabular}{|l} 
KEKUATAN \\
1. Fasilitas Terminal yang sudah \\
berstandar Internasional \\
2. Fasilitas Jalan yang Tanpa \\
gangguan \\
3. Fasilitas Transportasi \\
Penghubung yang efektif \\
4. Fasilitas Cargo yang aman \\
dan rapih \\
5. Fasilitas Penginapan yang \\
tersedia di area Bandara
\end{tabular} & $\begin{array}{l}\text { KELEMAHAN } \\
\text { 1. Kurangnya Fasilitas Toilet yang } \\
\text { disediakan } \\
\text { 2. Kurangnya Transportasi } \\
\text { penghubung yang diberikan } \\
\text { 3. Buruknya kualitas fasilitas } \\
\text { pendukung di dalam penginapan } \\
\text { 4. Stabilitas Jalan yang tidak } \\
\text { nyaman } \\
\text { 5. Tidak terjaganya keamanan } \\
\text { penyimpanan Barang }\end{array}$ \\
\hline PELUANG & STRATEGI SO & STRATEGI WO \\
\hline $\begin{array}{l}\text { 1. Meningkatnya jumlah } \\
\text { Penumpang di Terminal } \\
\text { 2. Terbukanya kesempatan } \\
\text { menarik pembeli di area } \\
\text { konsesi } \\
\text { 3. Meningkatnya traffic } \\
\text { kendaraan di area Bandara } \\
\text { 4. Bertambahnya jumlah } \\
\text { penumpang yang } \\
\text { menggunakan transportasi } \\
\text { umum } \\
\text { 5. Pengantaran bisnis barang } \\
\text { meningkat }\end{array}$ & $\begin{array}{l}\text { 1. Menggarap peluang yang ada } \\
\text { dengan melakukan } \\
\text { pengembangan terhadap } \\
\text { Bangunan Terminal } \\
\text { 2. Melakukan Perluasan Fasilitas } \\
\text { Cargo untuk menambah daya } \\
\text { tampung kapasitas barang } \\
\text { 3. Menambahkan armada } \\
\text { Kendaraan umum dan } \\
\text { membuat alternatif berupa } \\
\text { pembangunan transportasi } \\
\text { umum lain }\end{array}$ & $\begin{array}{l}\text { 1. Melakukan Pembangunan dan } \\
\text { Pengembangan Infrastruktur jalan } \\
\text { baik menuju maupun keluar } \\
\text { Bandara } \\
\text { 2. Meningkatkan pemeliharaan } \\
\text { Jalan di kawasan Bandara }\end{array}$ \\
\hline
\end{tabular}




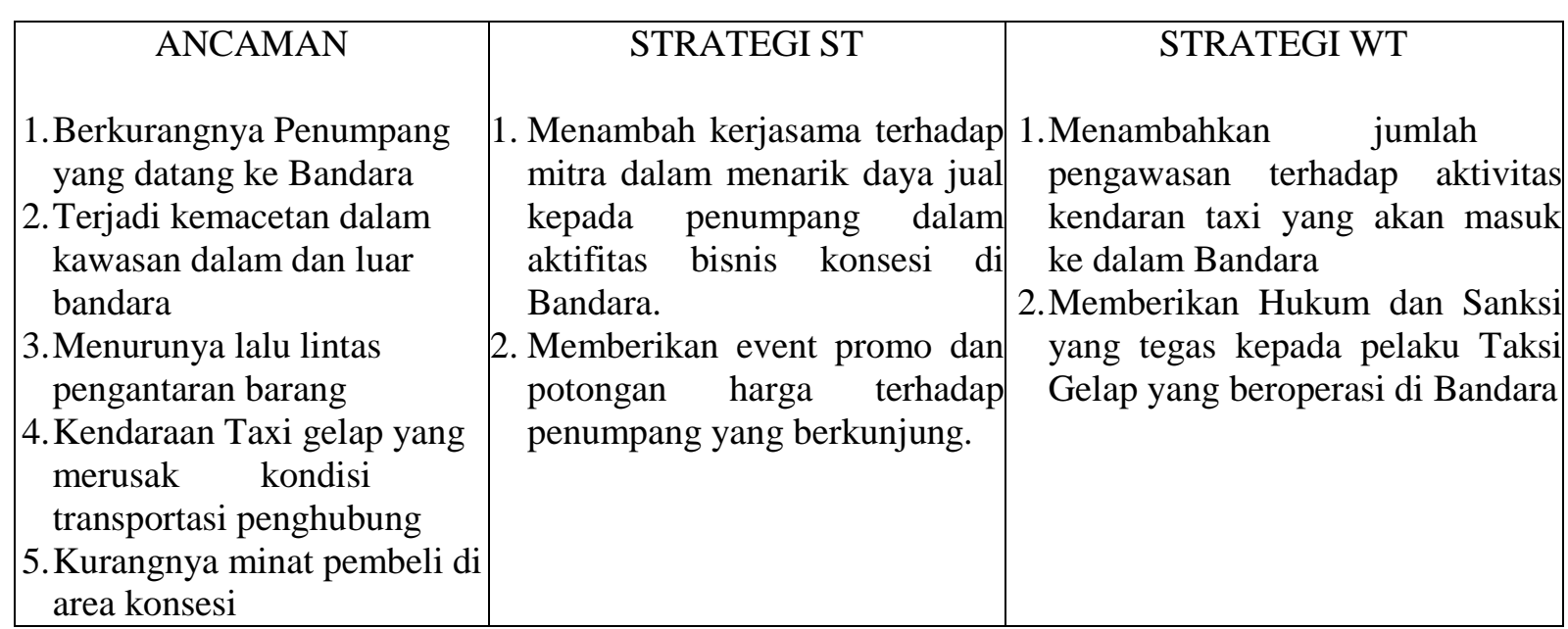

Berdasarkan Matrix SWOT diatas dapat dijelaskan bahwa ada 4 strategi yang dapat digunakan oleh Bandara Soekarno Hatta untuk mengembangkan Infrastruktur dalam meningkatkan pelayanan penumpang. Strategi tersebut sebagai berikut:

1. Strategi SO

Startegi ini memanfaatkan seluruh kekuatan untuk merebut dan memanfaatkan peluang yang sebesar- besarnya. Dalam hal ini Bandara Soekarno Hatta melakukan pengembangan terhadap Bangunan Terminal. Dengan menambah luasan area Terminal, diharapkan dapat menampung banyaknya jumlah pertumbuhan kapasitas penumpang yang melakukan aktivitas di Kawasan Bandara. Penambahan yang dimaksud, juga meliputi fasilitas pendukung seperti toilet, ruang tunggu, conter check-in, self check-in, mushola dan lain lain. Dari sisi pelayanan kargo, Bandara dapat melakukan perluasan fasilitas kargo baik dari sisi luasan Terminal dan menambah alat dukung penunjang untuk aktivitas dilingkungan kargo. Dengan menambahnya kapasitas daya tampung dan kualitas pelayanan akan sangat memberikan pertumbuhan aktivitas kargo sehingga kualitas pelayanan bagi penumpang dan pengguna jasa kargo akan meningkat. Strategi lain dapat meningkatkan daya tampung kapasitas barang dan menambahkan armada kendaraan umum dan membuat alternatif berupa pembangunan transportasi umum lain. Strategi ini dilakukan dalam upaya untuk memberikan pelayanan yang prima kepada penumpang bandara serta memberikan kemudahan transportasi penumpang dan barang di area Bandara Soekarno Hatta serta meningkatkan kapasitas daya tampung barang para pengguna jasa transportasi udara.

2. Strategi WO

Strategi ini diterapkan berdasarkan pemanfaatan peluang yang ada dengan cara meminimalkan kelemahan yang ada. Strategi WO yang dimiliki antara lain yaitu melakukan pembangunan dan pengembangan infrastruktur jalan baik menuju maupun keluar Bandara dan meningkatkan pemeliharaan jalan di kawasan Bandara. Upaya ini dilakukan untuk menghindari kemacetan dan memberikan kelancaran mobilitas para penumpang menuju atau keluar dari bandara.

3. Strategi ST

Strategi dalam menggunakan kekuatan yang dimiliki perusahaan untuk mengatasi ancaman. Dalam hal ini strategi ST yaitu menambah kerjasama terhadap mitra dalam menarik daya jual kepada penumpang dalam aktifitas bisnis konsesi di Bandara. Dengan semakin banyaknya mitra yang berkerjasama dengan Bandara dapat memberikan pilihan 
bagi penumpang untuk bertransaksi jual beli barang yang diinginkan. Selain dari pada banyaknya konsesi yang ditawarkan kepada penumpang, dengan memberikan event promo dan potongan harga terhadap penumpang yang berkunjung akan menjadi cara dalam mengatasi ancaman terhadap sepinya pembeli dari penumpang yang datang ke Bandara. Sehingga pelayanan dan kualitas yang diberikan kepada penumpang menjadi baik. Upaya ini memberikan kemudahan kepada para penumpang untuk mendapatkan berbagai kebutuhan yang diperlukan.

4. Strategi WT

Strategi ini berdasarkan pada kegiatan yang bersifat defensive dan berusaha meminimalkan kelemahan yang ada serta menghindari ancaman. Upaya yang dilakukan antara lain: menambahkan jumlah pengawasan terhadap aktivitas kendaran taxi gelap yang akan masuk ke dalam Bandara dan memberikan hukum dan sanksi yang tegas kepada pelaku taksi gelap yang beroperasi di Bandara. Sehingga keberadaan taksi gelap yang beroperasi di kawasan Bandara akan menjadi hilang. Jika taksi gelap yang beroperasi di area Bandara berkurang maka kesempatan untuk berkompetisinya transportasi umum akan menjadi sehat serta memberikan rasa aman. Dengan adanya hal tersebut dapat memberikan rasa aman dan nyaman kepada para penumpang atau pengguna jasa bandara.

\section{KESIMPULAN DAN SARAN}

Berdasarkan hasil dan pembahasan penelitian maka dapat disimpulkan bahwa Bandara Internasional Soekarno-Hatta dengan total nilai rata-rata tertimbang 2,885 pada matrix IFAS menunjukkan strategi perusahaan dalam memanfaatkan kekuatan dan meminimalkan kelemahan berada di atas rata-rata dan kondisi internal perusahaan cenderung kuat. Sedangkan nilai faktor eksternal Bandara Internasional Soekarno-Hatta di atas rata-rata 2,5, Bandara Internasional Soekarno-Hatta harus tetap berupaya maksimal untuk memanfaatkan peluang eksternal dan menghindari ancaman yang dapat mempengaruhi perusahaan. Terdapat empat alternatif strategi yang dapat diterapkan Bandara Internasional Soekarno Hatta Cengkareng sehubungan dengan pengembangan infrastruktur dalam meningkatkan pelayanan penumpang di Bandara Internasional Soekarno Hatta Cengkareng. Dari empat strategi tersebut (SO, WO, ST, WT) digunakan untuk diterapkan dalam pengembangan strategi yang dapat disarankan pada manajemen Bandara Internasional Soekarno Hatta Cengkareng.

Berdasarkan analisis hasil penelitian maka dalam meningkatkan pelayanan kepada penumpang diperlukan pengembangan infrastruktur jalan akses dilingkungan dan diluar Bandara serta pengembangan pusat perbelanjaan untuk memberikan kemudahan kepada para penumpang dalam memenuhi kebutuhan. Selain itu, perlu pengembangan dalam pembangunan area parkir transportasi umum.

\section{DAFTAR RUJUKAN}

Destiani, Dwi Putri. (2014). Analisis Strategi Model Bisnis Kanvas Pada PT Angkasa Pura II untuk Bandara Internasional Soekarno-Hatta. Masters Thesis. Institut Pertanian Bogor.

Fahmi, Irham. 2013. Manajemen Pengambilan Keputusan, Teori dan Aplikasi. Bandung : Penerbit Alfabeta

Fatoni, 2015. http://repository.uin-suska.ac.id/6664/4/BAB\%20III.pdf, (6 Oktober 2019 jam 08.15) 
Liu, dkk. 2009. Strategi Peningkatan Pelayanan Prasarana Transportasi Di Nusa Tenggara Timur. Nisak, Zuhrotun. 2013. http://journal.unisla.ac.id/pdf/12922013/4.pdf. (25 September 2019 jam 22.28)

Rangkuti, Freddy. 2006. Analisis Swot Teknik Membedah Kasus Bisnis. Gramedia Pustaka Utama. Jakarta.

Rifka dkk, 2010. Strategi Pengembangan Infrastruktur dalam Menunjang Kegiatan Wisata di Kampung Jawa Tondano

Sulistiani, Dwi. 2015. Analisis Swot Sebagai Strategi Perusahaan dalam Memenangkan Persaingan Bisnis. Siagian, Sondang P. 2003. Manajemen Strategi, Jakarta :Bumi Aksara.

Subekti, Siti (2016). Strategi Pengembangan Bandar Udara H. Hasan Aroeboesman Ende Dalam Meningkatkan Pelayanan Penumpang

Yuliana, Diana (2015). Strategi Pengembangan Pelayanan Publik di Bandar Udara Internasional Soekarno Hatta Cengkareng.Jurnal Perhubungan Udara.41 (4), 181-200. https://id.wikipedia.org/wiki/Bandar_Udara_Internasional_SoekarnoHatta https://id.wikipedia.org/wiki/Infrastruktur_bandar_udara 